\title{
PENILAIAN KINERJA KEUANGAN DENGAN ANALISIS RASIO KEUANGAN PADA PERUSAHAAN ASURANSI YANG GO PUBLIC DI BURSA EFEK INDONESIA (BEI) TAHUN 2013
}

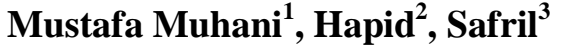 \\ 1) Dosen Sekolah Tinggi Ilmu Ekonomi Muhammadiyah Palopo \\ ${ }^{2,3)}$ Dosen Sekolah Tinggi Ilmu Ekonomi Muhammadiyah Palopo
}

\begin{abstract}
Abstrak: Tujuan penelitian ini adalah untuk menganalisis apakah kinerja keuangan perusahaan asuransi yang terdaftar di Bursa Efek Indonesia (BEI) tahun 2013 mencerminkan kinerja keuangan yang baik jika diukur dengan menggunakan analisis Rasio Likuiditas, Rasio solvabilitas, dan Rasio profitabilitas.. Sampel dalam penelitian ini adalah keseluruhan populasi, yaitu sebanyak sebelas perusahaan Asuransi yang terdaftar di BEI Tahun 2013.

Hasil penelitian Curren ratio menunjukkan terdapat lima perusahaan aruransi yang memiliki kinerja keuangan yang baik karena memiliki nilai curren ratio di atas standar rasio yang telah ditetapkan sebanyak 2 kali. Sementara enam perusahaan asuransi lain memiliki kinerja keuangan yang kurang baik karena memiliki nilai rasio di bawah standar. Cash Ratio menunjukkan terdapat empat perusahaan yang memiliki kinerja keuangan yang baik karena memiliki nilai di atas standar rasio kas yaitu 50\% atau 0,50. dan tujuh perusahaan yang lain memiliki kinerja keuangan yang kurang baik jika dilihat dari cash ratio karena dibawah dari standar rasio yang telah ditetapkan.

Debt to Equity Ratio menunjukkan empat perusahaan yang memiliki kinerja keuangan yang baik karena memiliki nilai rasio lebih kecil dari standar debt to equity ratio yaitu sebesar $90 \%$. Sedangkan tujuh perusahaan asuransi yang lain menunjukkan kinerja yang kurang baik karena berada di bawah standar rasio yang telah ditetapkan. Debt to Asset Ratio menunjukkan terdapat dua perusahaan yang memiliki kinerja keuangan yang baik karena memiliki rasio lebih kecil dari 35\% yang merupakan standar rasio yang telah ditetapkan. Dan sembilan perusahaan yang lain yaitu memiliki kinerja keuangan yang kurang baik karena memiliki nilai rasio di atas $35 \%$.

ROA mengambarkan bahwa semua perusahaan memiliki kinerja keuangan yang sangat baik karena memiliki nilai ROA lebih besar dari standar rata-rata rasio yang telah ditetapkan yaitu 1,25\%. Artinya semua perusahaan memanfaatkan asset yang dimiliki secara efisien untuk memperoleh laba secara maksimal. Perusahaan asuransi dengan nilai ROA tertinggi adalah PT. Maskapai Reasuransi Indonesia dengan persentase sebesar 10,58\%. ROE Menunjukkan dari sebelas perusahaan asuransi yang diteliti terdapat sembilan perusahaan yang memiliki kinerja keuangan yang baik, PT. Maskapai Reasuransi Indonesia merupakan perusahaan dengan persentase nilai ROE tertinggi yaitu 25,55\%. Sementara dua perusahaan yang memiliki kinerja keuangan yang kurang baik adalah PT. Asuransi Jasa Tania (6,53\%) dan PT. Lipo General Insurance (7,27\%) berada di bawah standar rasio yang telah ditetapkan yaitu 8,32\%.
\end{abstract}

Kata Kunci: Kinerja Keuangan, Asuransi, Rasio Likuiditas, Rasio Solvbilitas, Rasio Profitabilitas.

\section{PENDAHULUAN}

Pada umumnya suatu perusahaan didirikan dengan maksud agar perusahaan tersebut dapat berkembang serta mampu menjaga dan mempertahankan kelangsungan usahanya di masa yang akan datang. Kelangsungan hidup perusahaan merupakan ukuran kinerja perusahaan sebagai lawan dari kebangkrutan. Akan tetapi, dengan kondisi ekonomi yang terus menerus mengalami perubahan, maka keadaan ini dapat mempengaruhi kinerja dan keadaan perusahaan.
Industri asuransi berkembang selaras dengan perkembangan dunia usaha pada umumnya. Kehadiran industri asuransi merupakan hal yang rasional dan tidak terelakkan pada situasi dimana sebagian besar anggota masyarakat dan pengusaha memiliki kecenderungan umum untuk menghindari atau mengalihkan resiko kerugian atas segala yang dimiliki. Hal tersebut jika tidak dipertimbangkan upaya perlindungan dari berbagai risiko, dapat menimbulkan kerugian financial yang tidak sedikit. Perusahaan asuransi merupakan 
bagian dari lembaga keuangan yang sangat dibutuhkan oleh masyarakat. Menurut Siamat (2001:5) lembaga keuangan merupakan badan usaha yang kekayaannya terutama dalam bentuk asset keuangan atau tagihan (claims) dibandingkan aset non finansial atau asset riil.

Menurut Lidyawati (2004:14) Kinerja suatu perusahaan mencerminkan hasil dari serangkaian proses dengan mengorbankan berbagai sumber daya sehingga dengan demikian, perusahaan harus efektif dan efisien dalam mengelola sumber daya yang dimiliki agar dapat mempertahankan dan meningkatkan kinerjanya yang dicerminkan dari laporan keuangan yang dibuat oleh manajemen secara teratur. Semakin tinggi kinerja perusahaan maka semakin sehat perusahaan tersebut.

Analisis laporan keuangan, khusus mencurahkan perhatian pada perhitungan rasio agar mudah dievaluasi keadaan keuangan suatu perusahaan baik masa yang lalu, masa kini dan masa yang akan datang yang merupakan cara yang paling umum dipakai untuk menganalisa laporan keuangan, dengan kata lain untuk mengukur kekuatan dan kelemahan keuangan suatu perusahaan dapat dianalisa melalui rasio keuangan yang dinyatakan dalam artian relatif maupun absolut untuk menjelaskan hubungan tertentu antara faktor yang satu dengan faktor yang lainnya yang terdapat di dalam laporan keuangan.

\section{BAHAN DAN METODE}

Lokasi penelitian ini dilakukan di Bursa Efek Indonesia. Data diperoleh dengan mengakses www.idx.co.id. Berdasarkan jenisnya, data yang disajikan dalam penelitian ini adalah data kualitatif dan data kuantitatif . Data kualitatif dalam penelitian ini adalah riwayat atau sejarah perusahaan asuransi yang terdaftar di BEI, sedangkan data kuantitatif adalah data laporan keuangan perusahaan asuransi yang go public di BEI tahun 2013. Sumber data dalam penelitian ini adalah data sekunder yaitu data laopran keuangan dari tahun 2013 yang diperoleh secara tidak langsung melalui perantara, seperti orang lain atau dokumen, selain itu juga diperoleh dengan cara mengunjungi situs resmi dari masing-masing perusahaan yang diteliti.

Populasi dalam penelitian ini adalah seluruh perusahaan asuransi yang terdafar di Bursa Efek Indonesia (BEI) tahun 2013 yaiu sebanyak sebelas perusahaan. Sampel dalam penelitian ini adalah keseluruhan dari populasi dengan krieria yang telah ditetapkan, yaiu: perusahaan asuransi yang terdaftar di Bursa Efek Indonesia (BEI) dan perusahaan yang menerbitkan laporan keuangan yang telah diaudit untuk periode yang berakhir 31 Desember tahun 2013.

\section{HASIL DAN PEMBAHASAN}

\section{Rasio Likuiditas}

Rasio likuiditas merupakan rasio yang menggambarkan kemampuan suatu perusahaan untuk menyelesaikan kewajiban jangka pendeknya. rasio-rasio ini dapat dihitung melalui sumber informasi tentang modal kerja yaitu pospos asset lancar dan utang lancar.

Rasio likuiditas tidak hanya berkenaan dengan keadaan keseluruhan keuangan perusahaan, tetapi juga berkenaan dengan kemampuannya untuk mengubah asset lancar 
tertentu menjadi uang kas. Perusahaan harus mengubah asset lancar tertentu menjadi kas untuk membayar kewajiban lancarnya, Menurut Kasmir (2008:143) standar rasio likuiditas adalah sebagai berikut:

\section{Standar Rasio Likuiditas}

\begin{tabular}{|c|l|l|}
\hline No & \multicolumn{1}{|c|}{ Jenis Rasio } & \multicolumn{1}{|c|}{$\begin{array}{c}\text { Standar } \\
\text { Rasio }\end{array}$} \\
\hline 1 & Curren Ratio & 2 Kali \\
\hline 2 & Quick Ratio & 1,5 Kali \\
\hline 3 & Cash Ratio & $50 \%$ \\
\hline 4 & Cash Trun Over & $10 \%$ \\
\hline 5 & $\begin{array}{l}\text { Inventory to Net } \\
\text { Working Capital }\end{array}$ & $12 \%$ \\
\hline
\end{tabular}

\section{Nilai Curren Ratio}

\begin{tabular}{|c|l|r|r|c|}
\hline NO & \multicolumn{1}{|c|}{ NAMA PERUSAHAAN } & \multicolumn{1}{c|}{$\begin{array}{c}\text { CURREN } \\
\text { ASSET }\end{array}$} & $\begin{array}{c}\text { CURREN } \\
\text { LIABILITIES }\end{array}$ & $\begin{array}{c}\text { Curren } \\
\text { Ratio }\end{array}$ \\
\hline 1 & PT. Asuransi Bina Arta & $2,146,943,568$ & $1,305,735,127$ & $1.64 \mathrm{Kali}$ \\
\hline 2 & $\begin{array}{l}\text { PT Asuransi Harta Aman } \\
\text { Pratama }\end{array}$ & $277,628,662,518$ & $191,529,098,763$ & $1.45 \mathrm{Kali}$ \\
\hline 3 & $\begin{array}{l}\text { PT. Asuransi Multi Artha } \\
\text { Guna }\end{array}$ & $1,332,205,675$ & $487,033,917$ & $2.74 \mathrm{Kali}$ \\
\hline 4 & PT. Asuransi Bintang & $349,124,299$ & $42,410,876$ & $8.23 \mathrm{Kali}$ \\
\hline 5 & PT Asuransi Dayin Mitra & $1,077,942,808$ & $894,128,123$ & $1.21 \mathrm{Kali}$ \\
\hline 6 & PT. Asuransi Jasa Tania & $183,800,023,563$ & $113,200,999,355$ & $1.62 \mathrm{Kali}$ \\
\hline 8 & PT. Asuransi Ramayana & $1,072,312,474,018$ & $899,014,950,518$ & $1.19 \mathrm{Kali}$ \\
\hline 9 & PT. Lipo General Insurance & $1,659,034,200,416$ & $771,681,698,871$ & $2.15 \mathrm{Kali}$ \\
\hline 10 & PT. Mankapai Reasuransi & $857,787,928,276$ & $546,815,475,998$ & $1.57 \mathrm{Kali}$ \\
\hline 11 & PT. Panin Financial & $16,356,779$ & $3,810,042$ & $4.29 \mathrm{Kali}$ \\
\hline
\end{tabular}

Sumber:

Hasil pengolahan data laporan keuangan perusahaan asuransi yang go public di BEI tahun 2013.

\section{Curren Ratio}

Current ratio menunjukkan hubungan antara asset lancar dengan kewajiban lancar suatu perusahaan. Asset lancar umumnya meliputi kas, sekuritas, piutang usaha, dan persediaan. Sedangkan kewajiban lancar terdiri atas utang usaha, wesel tagih jangka pendek, utang jatuh tempo yang kurang dari satu tahun, akrual pajak, dan beban-beban akrual lainnya (terutama gaji). Semakin besar perbandingan antara asset lancar dan utang lancar maka semakin tinggi pula kemampuan perusahaan dalam menutupi kewajiban jangka pendeknya. Berikut ini adalah tabel dari curren ratio. 
Standar current ratio adalah sebanyak 2 kali. Berdasarkan nilai dari curren ratio di atas dapat dilihat bahwa terdapat lima perusahaan aruransi yang memiliki kinerja keuangan yang baik karena memiliki nilai curren ratio di atas standar rasio yang telah ditetapkan sebanyak 2 kali yaitu PT. Asuransi Multi Artha Guna, PT. Asuransi Bintang, PT. Lipo General Insurance, PT. Panin Insurance dan PT. Panin Financial dengan nilai carren ratio berturut-turut adalah $(2.74$ Kali, 8.23 Kali, 2.15 Kali, 4.29 Kali dan 4.37 Kali). Artinya hanya ada lima perusahaan yang mampu memenuhi kewajiban jangka pendeknya yang segera jatuh tempo dengan menggunakan asset lancar yang dimiliki oleh.

Sementara enam perusahaan yang lain menunjukkan kinerja kurang baik karena memiliki curren ratio di bawah 2 kali yaitu PT. Asuransi Bina Arta, PT Asuransi Harta Aman Pratama, PT Asuransi Dayin Mitra, PT. Asuransi Jasa Tania, PT. Asuransi Ramayana dan PT. Maskapai
Reasuransi Indonesia dengan nilai ratio bertutut-turut (1.64 Kali, 1.45 Kali, 1.21 Kali, 1.62 Kali, 1.19 Kali dan 1.57 Kali). Hal ini menunjukkan bahwa untuk memenuhi kewajiban jangka pendeknya tidak hanya dapat ditutupi dengan asset lancar tetapi memerlukan asset yang lain yang dimiliki oleh perusahaan tersebut untuk memenuhi kewajiban jangka pendek yang akan jatuh tempo.

\section{Cash Ratio}

Cash ratio merupakan rasio untuk mengukur seberapa besar uang kas yang tersedia untuk membayarkan utang. Hal ini ditunjukkan dari tersedianya dana kas atau setara kas seperti rekening giro. Semakin besar perbandingan kas atau setara kas dengan hutang lancar akan semakin baik. Berikut ini adalah tabel cash ratio.

\section{Nilai Cash Ratio}

\begin{tabular}{|c|l|r|r|r|}
\hline NO & NAMA PERUSAHAAN & \multicolumn{1}{c|}{ CHAS } & \multicolumn{1}{c|}{$\begin{array}{c}\text { CURREN } \\
\text { LIABILITIES }\end{array}$} & \multicolumn{1}{c|}{$\begin{array}{c}\text { Cash } \\
\text { Ratio }\end{array}$} \\
\hline 1 & PT. Asuransi Bina Arta & $798,029,879$ & $1,305,735,127$ & $61,12 \%$ \\
\hline 2 & $\begin{array}{l}\text { PT Asuransi Harta Aman } \\
\text { Pratama }\end{array}$ & $6,093,642,616$ & $191,529,098,763$ & $3,18 \%$ \\
\hline 3 & $\begin{array}{l}\text { PT. Asuransi Multi Artha } \\
\text { Guna }\end{array}$ & $782,371,000$ & $487,033,917$ & $160,64 \%$ \\
\hline 4 & PT. Asuransi Bintang & $6,419,705$ & $42,410,876$ & $15,1 \%$ \\
\hline 5 & PT Asuransi Dayin Mitra & $13,330,979$ & $894,128,123$ & $1,49 \%$ \\
\hline 6 & PT. Asuransi Jasa Tania & $8,465,068,981$ & $113,200,999,355$ & $7,48 \%$ \\
\hline 7 & PT. Asuransi Ramayana & $35,190,227,049$ & $899,014,950,518$ & $3,91 \%$ \\
\hline 8 & PT. Lipo General Insurance & $14,011,678,221$ & $771,681,698,871$ & $19,55 \%$ \\
\hline 9 & PT. Maskapai Reasuransi & $47,931,974,382$ & $546,815,475,998$ & $8,77 \%$ \\
\hline 10 & PT. Panin Insurance & $3,863,816$ & $3,810,042$ & $101,41 \%$ \\
\hline 11 & PT. Panin Financial & $3,704,599$ & $3,397,705$ & $109,03 \%$ \\
\hline
\end{tabular}


Berdasarkan data dari tabel di atas dapat dilihat bahwa terdapat empat perusahaan yang memiliki kinerja keuangan yang baik karena memiliki nilai di atas standar rasio kas yaitu 50\% atau 0,50. Perusahaan tersebut adalah PT. Asuransi Bina Arta (61,12\%), PT. Asuransi Multi Artha Guna $(160,64 \%)$, PT. Panin Insurance $(101,41 \%)$ dan PT. Panin Financial (109,03\%). Artinya keempat perusahaan tersebut mampu memenuhi kewajiban jangka pendeknnya hanya dengan menggunakan kas atau setara kas tanpa harus menggunakan asset lancar yang lain untuk memenuhi kewajiban jangka pendeknya yang segera jatuh tempo.

Sementara itu tujuh perusahaan yang lain memiliki kinerja keuangan yang kurang baik jika dilihat dari cash ratio karena dibawah dari standar rasio yang telah ditetapkan, yaitu PT Asuransi Harta Aman Pratama (3,18\%), PT. Asuransi Bintang (15,1\%), PT Asuransi Dayin Mitra (1,49\%), PT. Asuransi Jasa Tania (7,48\%), PT. Asuransi Ramayana (3,91\%), PT. Lipo General Insurance $(19,55 \%)$ dan PT. Maskapai Reasuransi Indonesia $(8,77 \%)$. Hal ini menunjukkan bahwa dari ketujuh perusahaan tersebut untuk memenuhi kewajiban jangka pendeknya tidak dapat terpenuhi hana dengan menggunakan kas atau setara kas perusahaan, tetapi membutuhkan asset lancar yang lain untuk memenuhi kewajiban lancar yang segera jatuh tempo.

\section{Rasio Solvabilitas}

Rasio ini mengukur perbandingan dana yang disediakan oleh pemilik dengan dana yang dipinjam perusahaan dari kreditur. Rasio ini menunjukkan kemampuan perusahaan untuk memenuhi kewajiban finansialnya. Baik jangka panjang maupun jangka pendeknya. Menurut kasmir (2008:16) standar rasio solvabilitas adalah sebagai berikut:

\section{Standar Rasio Solvabilitas}

\begin{tabular}{|c|l|c|}
\hline NO & \multicolumn{1}{|c|}{ Jenis Rasio } & $\begin{array}{c}\text { Standar } \\
\text { Rasio } \\
\text { Solvabilitas }\end{array}$ \\
\hline 1 & $\begin{array}{l}\text { Debt to Asset } \\
\text { Ratio }\end{array}$ & $35 \%$ \\
\hline 2 & $\begin{array}{l}\text { Debt to Equity } \\
\text { Ratio }\end{array}$ & $90 \%$ \\
\hline 3 & $\begin{array}{l}\text { Long Term Debt } \\
\text { to Equity Ratio } \\
\text { (LTDtER) }\end{array}$ & 10 Kali \\
\hline 4 & $\begin{array}{l}\text { Times Interest } \\
\text { Earbed }\end{array}$ & 10 Kali \\
\hline 5 & $\begin{array}{l}\text { Fixed Change } \\
\text { Coverage }\end{array}$ & 10 Kali \\
\hline
\end{tabular}

\section{Debt to Equity Ratio}

Rasio ini diperoleh dengan cara membagi total utang dengan seluruh modal perusahaan. Rasio ini menggambarkan sejauh mana modal yang dimiliki oleh perusahaan dapat menutup seluruh kewajiban perusahaan. Rasio ini dimaksudkan untuk mengetahui pemakaian modal sendiri guna menjamin jumlah utang. Berikut ini adalah tabel debt to equit ratio. 
Nilai Debt to Equity Ratio (DER)

\begin{tabular}{|r|l|r|r|r|}
\hline NO & NAMA PERUSAHAAN & \multicolumn{1}{c|}{ Total Debt } & \multicolumn{1}{c|}{ Total Equity } & \multicolumn{1}{c|}{ DER (\%) } \\
\hline 1 & PT. Asuransi Bina Arta & $1,338,047,254$ & $816,313,353$ & $163,91 \%$ \\
\hline 2 & $\begin{array}{l}\text { PT Asuransi Harta Aman } \\
\text { Pratama }\end{array}$ & $196,162,248,332$ & $100,244,346,561$ & $195,68 \%$ \\
\hline 3 & $\begin{array}{l}\text { PT. Asuransi Multi Artha } \\
\text { Guna }\end{array}$ & $616,653,759$ & $862,074,629$ & $71,53 \%$ \\
\hline 4 & PT. Asuransi Bintang & $269,062,945$ & $128,043,912 \mathrm{~b}$ & $210,13 \%$ \\
\hline 5 & PT Asuransi Dayin Mitra & $901,458,990$ & $197,761,186$ & $455,83 \%$ \\
\hline 6 & PT. Asuransi Jasa Tania & $984,528,700,836$ & $183,233,63,677,807$ & $133,23 \%$ \\
\hline 7 & PT. Asuransi Ramayana & $623,888,042,426$ & $1,088,177,561,406$ & $537,31 \%$ \\
\hline 8 & PT. Lipo General Insurance & $577,417,522,393$ & $407,983,658,482$ & $141,53 \%$ \\
\hline 9 & $\begin{array}{l}\text { PT. Maskapai Reasuransi } \\
\text { Indonesia }\end{array}$ & $3,831,629$ & $13,899,870$ & $27,57 \%$ \\
\hline 10 & PT. Panin Insurance & $3,415,038$ & $12,770,356$ & $26,74 \%$ \\
\hline 11 & PT. Panin Financial & & & \\
\hline
\end{tabular}

Dari tabel di atas dapat digambarkan bahwa terdapat empat perusahaan yang memiliki kinerja keuangan yang baik karena memiliki nilai rasio lebih kecil dari standar debt to equity ratio yaitu sebesar 90\%. Perusahaan tersebut adalah PT. Asuransi Multi Artha Guna (71,53\%), PT. Lipo General Insurance (57,33\%), PT. Panin Insurance $(27,57 \%)$ dan PT. Panin Financial (26,74\%). Hal ini menunjukkan perusahaan dibiayai oleh utang dibahawa dari $90 \%$ sedangkan sisanya dibiayai oleh sumber penerimaan lain perusahaan atau dengan kata lain kemampuan perusahaan dalam membayar kewajiban jangka penjangnya semakin baik.

Sedangkan tujuh perusahaan asuransi yang lain menunjukkan kinerja yang kurang baik jika dilihat dari debt to equity ratio karena berada di bawah standar rasio yang telah ditetapkan. Perusahaan tersebut adalah PT. Asuransi Bina Arta (163,91\%), PT Asuransi Harta Aman Pratama (195,68\%), PT. Asuransi Bintang (210,13\%), PT Asuransi Dayin Mitra (455,83\%), PT. Asuransi
Jasa Tania (133, 23\%), PT. Asuransi Ramayana (537,31\%) dan PT. Maskapai Reasuransi Indonesia $(141,53 \%)$ artinya ketujuh perusahaan dibiayai lebih dari $90 \%$ oleh utang untuk kegiatan operasi perusahaan atau kemampuan perusahaan dalam memenuhi kewajiban jangka panjangnya kurang baik.

\section{Debt to Asset Ratio}

Debt to Asset Ratio merupakan rasio utang yang digunakan untuk mengukur perbandingan antara total hutang dengan total asset atau dengan kata lain seberapa besar asset dibiayai oleh utang. Semakin tinggi rasio ini, maka semakin kurang baik bagi perusahaan karena semakin besar asset yang dimiliki dibiayai oleh utang, begitupun sebaliknya jika rasio ini rendah, maka semakin baik karena semakin kecil asset yang dibiayai oleh utang. Berikut ini adalah tabel debt to asset ratio. 


\section{Debt to Asset Ratio}

\begin{tabular}{|c|l|r|r|c|}
\hline NO & \multicolumn{1}{|c|}{ NAMA PERUSAHAAN } & \multicolumn{1}{c|}{ Total Debt } & \multicolumn{1}{c|}{ Total Asset } & DAR (\%) \\
\hline 1 & PT. Asuransi Bina Arta & $1,338,047,254$ & $2,153,350,059$ & $62,14 \%$ \\
\hline 2 & $\begin{array}{l}\text { PT Asuransi Harta Aman } \\
\text { Pratama }\end{array}$ & $196,162,248,332$ & $296,406,594,893$ & $66,18 \%$ \\
\hline 3 & $\begin{array}{l}\text { PT. Asuransi Multi Artha } \\
\text { Guna }\end{array}$ & $616,653,759$ & $1,478,728,388$ & $41,70 \%$ \\
\hline 4 & PT. Asuransi Bintang & $269,062,945$ & $398,947,898$ & $67,44 \%$ \\
\hline 5 & PT Asuransi Dayin Mitra & $901,458,990$ & $1,099,220,176$ & $82,01 \%$ \\
\hline 6 & PT. Asuransi Jasa Tania & $115,443,297,499$ & $202,092,221,126$ & $57,12 \%$ \\
\hline 7 & PT. Asuransi Ramayana & $984,528,700,836$ & $1,167,762,378,643$ & $84,31 \%$ \\
\hline 8 & PT. Lipo General Insurance & $623,888,042,426$ & $1,712,065,603,832$ & $36,44 \%$ \\
\hline 9 & $\begin{array}{l}\text { PT. Maskapai Reasuransi } \\
\text { Indonesia }\end{array}$ & $577,417,522,393$ & $985,401,180,875$ & $58,60 \%$ \\
\hline 10 & PT. Panin Insurance & $3,831,629$ & $17,740,266$ & $21,60 \%$ \\
\hline 11 & PT. Panin Financial & $3,415,038$ & $16,194,161$ & $21,09 \%$ \\
\hline
\end{tabular}

Tabel di atas menunjukkan hanya terdapat dua perusahaan yang memiliki kinerja keuangan yang baik jika dilihat dari debt ratio karena memiliki rasio lebih kecil dari $35 \%$ yang merupakan standar rasio yang telah ditetapkan. Perusahaan tersebut adalah PT. Panin Insurance $(21,60 \%)$ dan PT. Panin Financial $(21,09 \%)$. Hal ini berarti kedua perusahaan tersebut menunjukkan bahwa asset-asset yang dimiliki hanya dibiayai oleh utang sekitar $22 \%$ sementara $78 \%$ dibiayai oleh sumber penerimaan lain. Dalam kondisi seperti ini akan membuat perusahaan semakin baik karena resiko perusahaan untuk bangkrut semakin kecil karena asset yang dimiliki hanya sebagian kecil dibiayai oleh utang.

Sementara Sembilan perusahaan yang lain yaitu PT. Asuransi Bina Arta $(62,14 \%)$, PT Asuransi Harta Aman Pratama (66, 18\%), PT. Asuransi Multi Artha Guna (41,70\%), PT. Asuransi Bintang (67,44\%), PT Asuransi Dayin Mitra (82,01\%), PT. Asuransi Jasa Tania (57,12\%), PT. Asuransi Ramayana (84,31\%), PT.
Lipo General Insurance (36,44\%) dan PT. Maskapai Reasuransi Indonesia (58,60\%) memiliki kinerja keuangan yang kurang baik karena memiliki nilai rasio di atas $35 \%$. Artinya dari kesembilan perusahaan tersebut untuk memperoleh asset-assetnya harus dibiayai oleh utang di atas 35\%, Hal ini menunjukkan perusahaan tersebut memiliki resiko yang sangat besar karena pendanaan dengan utang semakin besar dan semakin membuat sulit perusahaan untuk memperoleh tambahan pinjaman karena dikhawatirkan perusahaan tidak akan mampu melunasi utang-utangnya dengan asset yang dimiliki.

\section{Rasio Profitabilitas}

Rasio profitabilitas bertujuan untuk mengukur efektifitas manajemen yang tercermin pada imbalan dan hasil dari investasi. Rasio-rasio lain dapat memberikan petunjuk yang digunakan untuk menilai keefektifan dari operasi sebuah perusahaan, tetapi rasio profitabilitas akan 
menunjukkan kombinasi dari efek likuiditas, manajemen asset dan kewajiban pada hasil operasi perusahaan. Rasio ini akan memberikan jawaban akhir tentang efektivitas manajemen perusahaan. Rasio profitabilitas digunakan untuk mengevaluasi margin laba dari aktivitas operasi yang dilakukan perusahaan. Berikut ini adalah standar rasio profitabilitas Lukviarman (2006:36).

\section{Standar Rasio Profitabilitas}

\begin{tabular}{|c|l|c|}
\hline No & \multicolumn{1}{|c|}{ Jenis Rasio } & $\begin{array}{c}\text { Standar } \\
\text { Rasio }\end{array}$ \\
\hline 1 & $\begin{array}{l}\text { Gross Profit } \\
\text { Margin }\end{array}$ & $24,90 \%$ \\
\hline 2 & $\begin{array}{l}\text { Operating Profit } \\
\text { Margin }\end{array}$ & $10,80 \%$ \\
\hline 3 & Retrun on Asset & $1,25 \%$ \\
\hline 4 & $\begin{array}{l}\text { Return on } \\
\text { Investment }\end{array}$ & $5,08 \%$ \\
\hline 5 & Return on Equity & $8,32 \%$ \\
\hline
\end{tabular}

ROA adalah rasio yang digunakan untuk mengukur keuntungan bersih yang diperoleh dari penggunaan asset. Dengan kata lain, semakin tinggi rasio ini maka semakin baik produktivitas asset dalam memperoleh keuntungan bersih. Hal ini selanjutnya akan meningkatkan daya tarik perusahaan kepada investor. Peningkatan daya tarik perusahaan menjadikan perusahaan tersebut semakin diminati oleh investor, karena tingkat pengembalian atau deviden akan semakin besar. Berikut adalah tabel retrun on asset.

\section{Nilai Retrun on Asset (ROA)}

\begin{tabular}{|c|l|r|r|r|}
\hline NO & \multicolumn{1}{|c|}{ NAMA PERUSAHAAN } & \multicolumn{1}{c|}{$\begin{array}{c}\text { EAT } \\
\text { (Laba Bersih) }\end{array}$} & $\begin{array}{r}\text { Total Asset } \\
\text { (Total Harta) }\end{array}$ & \multicolumn{1}{c|}{ ROA(\%) } \\
\hline 1 & PT. Asuransi Bina Arta & $151,478,596$ & $2,153,350,059$ & $7,03 \%$ \\
\hline 2 & $\begin{array}{l}\text { PT Asuransi Harta Aman } \\
\text { Pratama }\end{array}$ & $21,070,540,427$ & $296,406,594,893$ & $7.11 \%$ \\
\hline 3 & PT. Asuransi Multi Artha Guna & $152,769,616$ & $1,478,728,388$ & $10,33 \%$ \\
\hline 4 & PT. Asuransi Bintang & $19,792,073$ & $398,947,898$ & $4,96 \%$ \\
\hline 5 & PT Asuransi Dayin Mitra & $32,841,044$ & $1,099,220,176$ & $2,99 \%$ \\
\hline 6 & PT. Asuransi Jasa Tania & $5,653,945,887$ & $202,092,221,126$ & $2,80 \%$ \\
\hline 7 & PT. Asuransi Ramayana & $33,721,738,766$ & $1,167,762,378,643$ & $2,89 \%$ \\
\hline 8 & PT. Lipo General Insurance & $79,133,870,657$ & $1,712,065,603,832$ & $4,62 \%$ \\
\hline 9 & PT. Maskapai Reasuransi & $104,250,117,295$ & $985,401,180,875$ & $10,58 \%$ \\
\hline 10 & Indonesia & $1,329,535$ & $17,740,266$ & $7,49 \%$ \\
\hline 11 & PT. Panin Insurance & $1,197,532$ & $16,194,161$ & $7,39 \%$ \\
\hline
\end{tabular}

Sumber:

Hasil pengolahan data laporan keuangan perusahaan asuransi yang go public di BEI tahun 2013. 
Tabel di atas mengambarkan bahwa semua perusahaan memiliki kinerja keuangan yang sangat baik karena memiliki nilai ROA lebih besar dari standar rata-rata rasio yang telah ditetapkan yaitu $1,25 \%$. Artinya semua perusahaan memanfaatkan asset yang dimiliki secara efisien untuk memperoleh laba secara maksimal. Perusahaan asuransi dengan nilai ROA tertinggi adalah PT. Maskapai Reasuransi Indonesia dengan persentase sebesar10,58\%.

\section{Retrun on Equity (ROE)}

ROE merupakan rasio yang membandingkan laba bersih dengan total ekuitas. ROE digunakan untuk mengukur tingkat pengembalian perusahaan dalam menghasilkan keuntungan dengan memanfaatkan ekuitas yang dimiliki oleh perusahaan. Rasio ini juga menunjukkan sejauh mana kemampuan perusahaan menghasilkan laba yang dapat diperoleh. Semakin tinggi ROE menunjukkan semakin efisien perusahaan menggunakan modal sendiri untuk menghasilkan laba bagi pemegang saham. Berikut adalah tabel retrun on equity.

Nilai Retrun on Equity (ROE)

\begin{tabular}{|c|l|r|r|r|}
\hline NO & \multicolumn{1}{|c|}{ NAMA PERUSAHAAN } & \multicolumn{1}{c|}{$\begin{array}{c}\text { EAT } \\
\text { (Laba Bersih) }\end{array}$} & \multicolumn{1}{c|}{$\begin{array}{c}\text { EQUITY } \\
\text { (Modal) }\end{array}$} & \multicolumn{1}{c|}{ ROE (\%) } \\
\hline 1 & PT. Asuransi Bina Arta & $151,478,596$ & $816,313,353$ & $18,56 \%$ \\
\hline 2 & $\begin{array}{l}\text { PT Asuransi Harta Aman } \\
\text { Pratama }\end{array}$ & $21,070,540,427$ & $100,244,346,561$ & $21,02 \%$ \\
\hline 3 & PT. Asuransi Multi Artha Guna & $152,769,616$ & $862,074,629$ & $17,72 \%$ \\
\hline 4 & PT. Asuransi Bintang & $19,792,073$ & $128,043,912$ & $15,46 \%$ \\
\hline 5 & PT Asuransi Dayin Mitra & $32,841,044$ & $197,761,186$ & $16,61 \%$ \\
\hline 6 & PT. Asuransi Jasa Tania & $5,653,945,887$ & $86,648,923,627$ & $6,53 \%$ \\
\hline 7 & PT. Asuransi Ramayana & $33,721,738,766$ & $183,233,677,807$ & $18,40 \%$ \\
\hline 8 & PT. Lipo General Insurance & $79,133,870,657$ & $1,088,177,561,406$ & $7,27 \%$ \\
\hline 9 & PT. Maskapai Reasuransi & $104,250,117,295$ & $407,983,658,482$ & $25,55 \%$ \\
\hline 10 & PT. Panin Insurance & $1,329,535$ & $13,899,870$ & $9,57 \%$ \\
\hline 11 & PT. Panin Financial & $1,197,532$ & $12,770,356$ & $9,38 \%$ \\
\hline
\end{tabular}

Sumber:

Hasil pengolahan data laporan keuangan perusahaan asuransi yang go public di BEI tahun 2013. 
Dari tabel di atas menunjukkan dari sebelas perusahaan asuransi yang diteliti terdapat sembilan perusahaan yang memiliki kinerja keuangan yang baik karena memiliki nilai ROE lebih besar dari $8,32 \%$. Data ini menunjukkan perusahaan telah memanfaatkan seluruh equity untuk kegiatan operasional perusahaan dengan efisien karena telah memperoleh laba dengan cukup besar. Perusahaan tersebut adalah PT. Asuransi Bina Arta (18,56\%), PT Asuransi Harta Aman Pratama (21,02\%), PT. Asuransi Multi Artha Guna (17,72\%), PT. Asuransi Bintang (15,46\%), PT Asuransi Dayin Mitra (16,61\%), PT. Asuransi Ramayana $(18,40 \%)$, PT. Maskapai Reasuransi Indonesia (25,55\%), PT. Panin Insurance $(9,57 \%)$ dan PT. Panin Financial (9,38\%). PT. Maskapai Reasuransi Indonesia merupakan perusahaan dengan persentase nilai ROE tertinggi yaitu $25,55 \%$.

Sementara dua perusahaan yang memiliki kinerja keuangan yang kurang baik adalah PT. Asuransi Jasa Tania (6,53\%) dan PT. Lipo General Insurance $(7,27 \%)$ berada di bawah standar rasio yang telah ditetapkan yaitu $8,32 \%$. Ini menunjukkan meskipun kedua perusahaan tersebut memiliki kinerja keuanga yang kurang baik tetapi tetap mampu memperoleh laba dengan seluruh equity yang dimiliki, meskipun penggunaan equity tersebut belum dimanfaatkan untuk kegiatan operasi perusahaan secara efisien.

\section{SIMPULAN}

Rasio Likuditas

\section{Current Ratio}

Terdapat lima perusahaan aruransi yang memiliki kinerja keuangan yang baik karena memiliki nilai curren ratio di atas standar rasio yang telah ditetapkan sebanyak 2 kali yaitu PT. Asuransi Multi Artha Guna, PT. Asuransi Bintang, PT. Lipo General Insurance, PT. Panin Insurance dan PT. Panin Financial dengan nilai carren ratio berturut-turut adalah (2.74 Kali, 8.23 Kali, 2.15 Kali, 4.29 Kali dan 4.37 Kali). Sementara enam perusahaan asuransi lain (PT. Asuransi Bina Arta, PT Asuransi Harta Aman Pratama, PT Asuransi Dayin Mitra, PT. Asuransi Jasa Tania, PT. Asuransi Ramayana dan PT. Maskapai Reasuransi Indonesia) dengan nilai ratio bertutut-turut (1.64 Kali, 1.45 Kali, 1.21 Kali, 1.62 Kali, 1.19 Kali dan 1.57 Kali) memiliki kinerja keuangan yang kurang baik karena memiliki nilai rasio di bawah standar sehingga membutuhkan asset yang lain yang tersebut untuk memenuhi kewajiban jangka pendek yang segera jatuh tempo.

\section{Cash Ratio}

Cash Ratio menunjukkan terdapat empat perusahaan yang memiliki kinerja keuangan yang baik karena memiliki nilai di atas standar rasio kas yaitu $50 \%$ atau 0,50 . Perusahaan tersebut adalah PT. Asuransi Bina Arta (61,12\%), PT. Asuransi Multi Artha Guna (160,64\%), PT. Panin Insurance $(101,41 \%)$ dan PT. Panin Financial $(109,03 \%)$. Sementara itu tujuh perusahaan yang lain memiliki kinerja keuangan yang kurang baik jika dilihat dari cash ratio karena dibawah dari standar rasio yang telah ditetapkan, yaitu PT Asuransi Harta Aman Pratama (3,18\%), PT. Asuransi Bintang $(15,1 \%)$, PT Asuransi Dayin Mitra (1,49\%), PT. Asuransi Jasa Tania (7,48\%), PT. Asuransi Ramayana $(3,91 \%)$, PT. Lipo General Insurance $(19,55 \%)$ dan PT. Maskapai Reasuransi Indonesia (8,77\%). Rasio Solvabilitas 


\section{Debt to Equity Ratio}

Debt to Equity Ratio menunjukkan empat perusahaan yang memiliki kinerja keuangan yang baik karena memiliki nilai rasio lebih kecil dari standar debt to equity ratio yaitu sebesar $90 \%$. Perusahaan tersebut adalah PT. Asuransi Multi Artha Guna (71,53\%), PT. Lipo General Insurance (57,33\%), PT. Panin Insurance (27,57\%) dan PT. Panin Financial (26,74\%). Sedangkan tujuh perusahaan asuransi yang lain menunjukkan kinerja yang kurang baik karena berada di bawah standar rasio yang telah ditetapkan. Perusahaan tersebut adalah PT. Asuransi Bina Arta (163,91\%), PT Asuransi Harta Aman Pratama (195,68\%), PT. Asuransi Bintang (210,13\%), PT Asuransi Dayin Mitra (455,83\%), PT. Asuransi Jasa Tania (133, 23\%), PT. Asuransi Ramayana (537,31\%) dan PT. Maskapai Reasuransi Indonesia (141,53\%).

\section{Debt to Asset Ratio}

Debt to Asset Ratio menunjukkan terdapat dua perusahaan yang memiliki kinerja keuangan yang baik jika dilihat dari debt ratio karena memiliki rasio lebih kecil dari $35 \%$ yang merupakan standar rasio yang telah ditetapkan. Perusahaan tersebut adalah PT. Panin Insurance (21,60\%) dan PT. Panin Financial (21,09\%). Sementara Sembilan perusahaan yang lain yaitu PT. Asuransi Bina Arta (62,14\%), PT Asuransi Harta Aman Pratama (66, 18\%), PT. Asuransi Multi Artha Guna (41,70\%), PT. Asuransi Bintang (67,44\%), PT Asuransi Dayin Mitra (82,01\%), PT. Asuransi Jasa Tania (57,12\%), PT. Asuransi Ramayana (84,31\%), PT. Lipo General Insurance $(36,44 \%)$ dan PT. Maskapai Reasuransi Indonesia $(58,60 \%)$ memiliki kinerja keuangan yang kurang baik karena memiliki nilai rasio di atas $35 \%$.

\section{Rasio Profitabilitas}

\section{Retrun on Asset (ROA)}

ROA mengambarkan bahwa semua perusahaan memiliki kinerja keuangan yang sangat baik karena memiliki nilai ROA lebih besar dari standar rata-rata rasio yang telah ditetapkan yaitu $1,25 \%$. Artinya semua perusahaan memanfaatkan asset yang dimiliki secara efisien untuk memperoleh laba secara maksimal. Perusahaan asuransi dengan nilai ROA tertinggi adalah PT. Maskapai Reasuransi Indonesia dengan persentase sebesar10,58\%.

Retrun on Equity (ROE)

ROE Menunjukkan dari sebelas perusahaan asuransi yang diteliti terdapat sembilan perusahaan yang memiliki kinerja keuangan yang baik karena memiliki nilai ROE lebih besar dari $8,32 \%$. Data ini menunjukkan perusahaan telah memanfaatkan seluruh equity untuk kegiatan operasional perusahaan dengan efisien karena telah memperoleh laba dengan cukup besar. Perusahaan tersebut adalah PT. Asuransi Bina Arta (18,56\%), PT Asuransi Harta Aman Pratama (21,02\%), PT. Asuransi Multi Artha Guna (17,72\%), PT. Asuransi Bintang (15,46\%), PT Asuransi Dayin Mitra $(16,61 \%)$, PT. Asuransi Ramayana (18,40\%), PT. Maskapai Reasuransi Indonesia $(25,55 \%)$, PT. Panin Insurance $(9,57 \%)$ dan PT. Panin Financial (9,38\%). PT. Maskapai Reasuransi Indonesia merupakan perusahaan dengan persentase nilai ROE tertinggi yaitu $25,55 \%$. Sementara dua perusahaan yang memiliki kinerja keuangan yang kurang baik adalah PT. Asuransi Jasa Tania (6,53\%) dan PT. Lipo General Insurance $(7,27 \%)$ berada di bawah standar rasio yang telah ditetapkan yaitu $8,32 \%$. 


\section{DAFTAR PUSTAKA}

Harahap, Sofyan. 2010. Analisis Kritis Laporan Keuangan. Jakarta: Rajawali Pers.

Helfert, Erich. A. 1997. "Techniques of Financial Analysis : A Practical Guide To Managing and Measuring Business Performance". Dialihbahasakan oleh Wibowo, Herman. Teknik Analisis Keuangan. Edisi Kedelapan. Jakarta: Erlangga.

Ikatan Akuntan Indonesia. 2009. Pernyataan Standar Akuntansi Keuangan No.1.Jakarta : Dewan Standar Akuntansi Keuangan.

Kasmir. 2008. Analisis Laporan Keuangan. Jakarta: PT RajaGrafindo Persada.

Kusmadiyanto, Andra. 2006 analisis Laporan Keuangan Untuk Menilai Kinerja Perusahaan Pada Kelompok Indusri Rokok. Skripsi: Bandung. Universitas Widyatama Bandung.

Lidyawati, Novy. 2004. Analisis Rasio Keuangan Sebagai Prediksi Perubahan Laba Perusahaan yang Terdaftar Di Pasar Modal Indonesia. Tesis. Semarang: Universitas Katolik Soegijapranata Semarang.

Merawati, Endang, Etty. 2008. Penilaian Perusahaan Asuransi dengan Risk Based Capital dan Early Warning System. Akuntabilitas. Volume (2).(1) September 2002, hal 23-33.

Sawir, Agnes. 2005. Analisis Kinerja Keuangan dan Perencanaan Keuangan Perusahaan. PT Gramedia Pustaka, Jakarta.

Sekaran, Uma. 2009. Research Methods for Business. Buku 1. Edisi 4. Jakarta: Salemba Empat.

2006. Research Methods for Business. Buku 2. Edisi 4. Jakarta: Salemba Empat.

Siamat, Dahlan. 2001. Manajemen Lembaga Keuangan. Edisi Ketiga. Jakarta : Lembaga Penerbit Fakultas Ekonomi Universitas Indonesia.
Sihombing, Daulat. 2008. Judul Peranan Analisis Rasio Keuangan Dalam Memprediksi Kesehaan Perusahaan Tekstil dan Alas Kaki yang Terdaftar Di Bursa Efek Jakarta, Tesis. Medan: Universitas Sumatra Utara. Medan.

Sugiono. 2010. Metode Penelitian Bisnis. Bnadung: Cv Alfabeta.

Susilo, Y. Sri. Triandaru, Sigit. Santoso, A. Totok Budi. 2000. Bank dan LembagaKeuangan Lain. Jakarta : Salemba Empat.

Undang-undang No. 2 Tahun 1992 Tentang Usaha Perasuransian.

WWW.Idx.co.id (Diakses Tanggal 25 Maret 2015, Pukul 13.15 Wita).

WWW.Daftar Perusahaan Asuransi Go Public Saham OK.htm (Diakses Tanggal 22 Maret 2015, Pukul 09.30 Wita). 